\title{
Wizerunek średniowiecznego Żyda
}

\author{
Anna Jaroszewska (Poznań)
}

Obraz Żydów z okresu średniowiecza jawi się jako pełen sprzeczności. Z jednej strony prezentowany jest jako lichwiarz zbijający fortunę dzięki narzucaniu ogromnych procentów, odczuwający wrogość do chrześcijan wyznawca obcej, tajemniczej religii, nierzadko oskarżany o rytualne mordy, aby zyskać krew niewinnych do swych magicznych obrzędów, zwolennik Antychrysta, dążący do zniszczenia świata i podporządkowania go swoim celom. Z drugiej strony Żydzi ówcześnie stanowili integralną część społeczności, nie tylko żyjąc pośród chrześcijan, lecz również prowadząc $\mathrm{z}$ nimi interesy bądź współpracując intelektualnie. Żydowscy filozofowie, jak Mojżesz Majmonides czy Awicebron (Ibn Gabirol) byli znani i szanowani przez chrześcijańskich myślicieli, żydowskich medyków wyjątkowo ceniono za ich rozległą wiedzę i umiejętności. Mimo nierzadkich przejawów sympatii, do Żydów podchodzono z nieufnością i pewnym dystansem. Po części spowodowane było to ich religią, tak odmienną od chrześcijaństwa, pełną niezrozumiałych dla chrześcijan praw i rytuałów. W judaizmie najrozmaitsze regulacje obejmowały każdą niemal dziedziny życia, wpływając tym samym na formę relacji Żydów z ich nieżydowskim otoczeniem społecznym. Również działania Kościoła katolickiego przyczyniały się do wzrostu nieufności i niechęci wobec społeczności żydowskiej, wzmacniania stereotypów, a coraz częściej do aktów antysemickich. Wprawdzie wydawane były papieskie dekrety i napomnienia, a wyższe duchowieństwo starało się usilnie zapobiegać aktom agresji i przemocy skierowanym przeciw Żydom, lecz nauki i zachowania niższych duchownych wręcz zachęcały do zachowań antysemickich. To właśnie w średniowieczu powstawały pierwsze getta pozwalające koncentrować, wyodrębniać, izolować, kontrolować i wreszcie marginalizować żydowską mniejszość na tle społeczności państw narodowych ówczesnego świata.

Wizerunek średniowiecznego Żyda ma więc charakter wielowymiarowy. W poniższym artykule podejmę próbę ujęcia tego charakteru, przywołując postać Żyda w roli kupca, lichwiarza, mieszkańca getta, jako wyznawcę obcej (względem chrześcijaństwa) religii, jako członka średniowiecznej społeczności z wszystkim prawami i narzucanymi ograniczeniami.

Za typowe zajęcie średniowiecznego Żyda uznaje się lichwę, czyli pożyczanie pieniędzy na procent (przeważnie dość wysoki). W istocie, znaczna część Żydów zajmowała się szeroko pojętymi usługami bankowymi, określanymi negatywnie lichwą. Zły odbiór tego zajęcia spowodowany był kilkoma czynnikami. Przede wszystkim lichwa była ostro potępiana przez Kościół: 
Masowa nienawiść do lichwiarzy zyskała najsilniejsze poparcie w polityce Kościoła, bo katolicyzm uważał lichwę za ciężki grzech, raczej ze względów dogmatycznych (opartych na biblijnym zakazie) niż ze społecznych: grzech przeciw Kościołowi Jezusowemu, a więc przeciw gatunkowi ludzkiemu, który ten starał się zbawić. Nieunikniony wzrost chrześcijańskiej lichwy zmuszał Kościół do stanowczości (Trachtenberg 1997, 166).

Richard Callimani stwierdza, że doktryna chrześcijańska opierała się na dwóch zasadach ekonomicznych: na zakazie pobierania procentów oraz na sugestii, by nie naprzykrzać się dłużnikowi o zwrot pożyczki (Callimani 2002). Lichwa, łamiąc te zasady, stopniowo urosła do rangi poważnego problemu, którym zmuszone było zająć się ustawodawstwo XII wieku. Zaliczono ją szybko do takich zbrodni jak czary, podpalanie, morderstwo, świętokradztwo, cudzołóstwo (ibid.). Również Kościół regulował sprawy związane z lichwą swoim autorytetem: odmawiając lichwiarzom prawa do świętych sakramentów i religijnego pochówku (ibid.) czy też w bulli papieża Aleksandra IV zrównując ją z herezją (Trachtenberg 1997). Zakazując chrześcijanom działalności lichwiarskiej, duchowni w pewnym sensie przyznali Żydom prawo do zajmowania się nią. Israel Abrahams w swojej pracy Życie codzienne Żydów w średniowieczu (1996) zauważa, iż na skutek polityki Kościoła Rzymskiego Żydom wręcz zabroniono pracować w rzemiośle i rękodziele, mogli jedynie zajmować się handlem starzyzną, dlatego zaczęli też udzielać pożyczek, a przez pewien czas jako pożyczkodawcy znajdowali się w pozycji uprzywilejowanej. W rezultacie średniowieczna społeczność chrześcijańska oceniała ich z jeszcze większą podejrzliwością i uznawała za gorszy gatunek ludzi, ponieważ mogli być lichwiarzami, co było zabronione dla chrześcijan (zakaz lichwy miał podłoże w Nowym Testamencie: w Ewangeliach zawarte są wyraźne zakazy pożyczania pieniędzy na procent, np. Łk 6,34-35; Mt 6, 24).W XII wieku słowa „lichwiarz” i „Żyd” stały się synonimami (Trachtenberg 1997). Stereotyp chciwego Żyda-lichwiarza, zyskującego majątek na nieszczęściu innych, powstał właśnie w tym okresie i funkcjonował niemal bez zmian przez kolejne stulecia.

Tak naprawdę Żydzi nie byli chytrymi lichwiarzami, którzy zbijali majątki na naiwności pożyczkobiorców. Jako bankierzy stanowili mocną podstawę handlową państw, w których rezydowali, byli zarazem silnie kontrolowani przez lokalne władze i ustawodawstwo. Instancje te regulowały wysokość oprocentowania pożyczek, zasady ich spłaty, warunki udzielania i zaciągania kolejnych pożyczek dla budżetu miejskiego czy państwowego. Żaden Żyd nie mógł udzielać pożyczek niezgodnych z lokalnymi przepisami, na swój procent i wedle swoich zasad! Stopy procentowe zmieniały się w zależności od czasu trwania umów między Żydami a miastem (tzw. condotta) oraz miejsca. Żydowscy bankierzy wprowadzili nowy mechanizm ekonomiczny: dzięki napływowi nowego kapitału w miastach i państwach rozwijać się mogły handel i wszelkiego typu działalność gospodarcza. Callimani podkreśla, że żydowscy bankierzy bywali zmuszani do udzielania pożyczek na drobne sumy. 
Przykładowo dzięki takim pożyczkom Republika Wenecja chciała osiągnąć spokój w społeczeństwie i zarazem sprawować kontrolę nad biedotą miejską (Callimani 2002). Wysokie pożyczki, proponowane miastu bądź władcom, miały znacznie korzystniejsze oprocentowanie. Żydzi oferowali pożyczki pod zastaw lub w przypadku wyższych kwot poświadczane jedynie na papierze, nie zabezpieczone. Większe pożyczki miały dodatkowo dłuższy termin zwrotu i wyższą stopę procentową.

Monopolistyczna pozycja Żydów jako bankierów utrwaliła się dopiero pod koniec średniowiecza, w XIV i XV wieku. W tym czasie nasiliły się ataki Kościoła. W wieku XV zdecydowanie przeciwko lichwie występowali w swych kazaniach franciszkanie, uznając ją za skazę na wierze. Z inicjatywy zakonników zaczęły powstawać chrześcijańskie lombardy. W założeniu była to alternatywa dla żydowskiej bankowości, która miała zaspokoić potrzeby ubogich bez narażania ich na skażenie duchowe, czyli kontakt z Żydami i udział w lichwie. Lombardy opierały się na darowiznach, za które ofiarodawca otrzymywał odpust-stanowiło to kapitał przeznaczony na drobne pożyczki dla potrzebujących. Działalność żydowskich banków była jednak znacznie szersza, zawierała także gwarancję dla dłużnika i poręczyciela, a swym zakresem obejmowała wsie i miasta. Chrześcijańskie lombardy zaczęły stanowić prawdziwą konkurencję dla żydowskiej bankowości dopiero wówczas, gdy zaczęły stosować niską stopę procentową. Władza polityczna i kler poprzez lombardy starały się ograniczyć wpływ i znaczenie banków żydowskich. Spory trwały aż do XVI wieku, bez trwałego rozwiązania.

Rozważanie alternatywy: banki albo lombardy nie prowadziło do zadowalającego rozstrzygnięcia, ponieważ każda $\mathrm{z}$ tych instytucji spełniała inną funkcję ekonomiczną. Lombard wymagał kapitałów bezzwrotnych, nie pomnażał zasobów, nie mógł być obciążony dużym podatkiem. Żydzi, których działalność była bardziej dynamiczna, giętka, mniej społeczna, jak by się dziś powiedziało, płacili na rzecz państwa wysokie podatki, można było od nich żądać kredytów przymusowych i pożyczali biednym po rozsądnej stopie procentowej, a wreszcie do otwarcia banku nie potrzebowali ogromnego funduszu założycielskiego, jak w przypadku lombardu (Callimani 2002, 63).

Ostatecznie idea lombardów wypaczyła się: przekształciły się one w banki prywatne, ulegając często wpływom bogatych patrycjuszy i odchodząc od swej podstawowej działalności, czyli udzielania pożyczek najuboższym. Kapitał żydowski okazał się łatwiejszy w kontrolowaniu, nie poddawał się zbytnim wpływom politycznym i (zwłaszcza w Wenecji) funkcjonował jako jedno z lepszych narzędzi do kontroli nad sferą ubóstwa (ibid.).

Poza lichwą, innym popularnym wśród średniowiecznych Żydów zajęciem było kupiectwo. Podobnie jak działalność bankowa, pełniło ono istotną rolę w średniowiecznej gospodarce. Żydzi jako społeczność migrująca miało wielorakie, złożone kontakty handlowe. Ułatwiały im one pracę; Żydzi mogli (jak miało to miejsce w Wenecji) wykorzystywać mniej uczęszczane 
szlaki handlowe typu lądowego, w sytuacji, gdy handel drogą morska stał się niebezpieczny. Żydzi wypędzeni z Hiszpanii i Portugalii na przełomie XV i XVI wieku dotarli do Wenecji, gdzie wykorzystano ich międzynarodowe koneksje i rozległe znajomości dla wzmocnienia weneckiego szlaku handlowego prowadzącego do Egiptu. Także później, w XVI wieku, kolejni żydowscy uchodźcy z Hiszpanii pomogli we wprowadzeniu zmian w handlu Wenecji - na morzu coraz częściej pojawiali się piraci, na skutek czego koniecznością okazało się znalezienie bezpiecznych lądowych szlaków handlowych. Hiszpańscy Żydzi dzięki swym znajomościom, koneksjom rodzinnym i dużej sprawności handlowej, ułatwili znalezienie tras lądowych na potrzeby Wenecji.

Żydzi byli jedynymi wielkimi kupcami-praktycznie rzecz biorąc, bez rywali w kołach chrześcijańskich-dopóki wielkie republiki włoskie nie przeorganizowały się zgodnie z zasadami komercyjnymi. Żydzi byli również pośrednikami i $\mathrm{w}$ detalicznym, i w hurtowym handlu europejskim (Abrahams 1996, 149).

Handel, w przeciwieństwie do lichwy, nie stawiał Żydów w negatywnym świetle. Mimo że bankowość żydowska była ceniona przez władze miast i państw, żydowscy bankierzy nie cieszyli się zbytnim szacunkiem wśród zwykłych obywateli. Handlarze natomiast oceniani byli znacznie pozytywniej. Doceniano również ich znaczącą rolę w rozwoju gospodarczym. Kontakty Żydów lewantyńskich ważne były dla rozwoju handlu Republiki Weneckiej, która starała się przez całe średniowiecze zachować swą istotną pozycję w handlu międzynarodowym. Żydzi hiszpańscy słynni byli $\mathrm{z}$ prowadzenia intensywnego handlu suknem i wełną. Po części wynikało to z uwarunkowań religijnych: Talmud uważał tkactwo za zajęcie poniżające, pozostawiając jedynie możliwość handlu gotowymi produktami (Abrahams 1996). Działając zgodnie z zaleceniami swojej religii, Żydzi uczynili z handlu swoją mocną stronę, dzięki której stali się ważnym elementem średniowiecznych miast.

Nieufność wobec Żydów nie wykluczała w miarę pokojowego egzystowania społeczności żydowskiej i chrześcijańskiej. Zdarzały się okresy napięć i zwiększonych ataków antysemickich, lecz w przeważającej większości Żydzi nie odczuwali wrogości współobywateli. Abrahams zwraca uwagę na fakt, że mimo istnienia regulacji prawnych mających na celu rozdział obu społeczności Żydzi oraz chrześcijanie nie zwracali na nie większej uwagi. Za tworzenie barier odpowiadał przede wszystkim Kościół.

Duża zmiana $\mathrm{w}$ stosunkach społecznych nastąpiła w XIII wieku, po pierwszych wyprawach krzyżowych. Żydów zaczęto traktować na równi $\mathrm{z}$ heretykami, często widząc w nich zagrożenie dla wiary chrześcijańskiej. Misteria chrześcijańskie duży nacisk kładły na rolę Żydów w męce Chrystusa. Tym samym dawano do zrozumienia, że są wspólnikami diabła, chcącymi zniszczyć chrześcijaństwo. Różnego rodzaju legendy głosiły, że w swych modlitwach Żydzi modlą się właśnie o zagładę chrześcijan: 
... misteria, sztuki o cudownych wydarzeniach i moralitety, kroniki i legendy, poematy, baśnie ludowe i pieśni, wszystko to przedstawia Żyda jako źródło wszelkiego zła, jako popełniającego z premedytacją nieopisane zbrodnie przeciw założycielowi religii chrześcijańskiej i przeciw Kościołowi chrześcijańskiemu oraz indywidualnie przeciw jego wyznawcom. Nie ma grzechu zbyt plugawego, aby mu go przypisać; lecz najokropniejszym jego występkiem był rzekomy zamiar unicestwienia chrześcijaństwa i wiary chrześcijańskiej. Żyd był zaprzysięgłym wrogiem ludzkości (Trachtenberg 1997, 22).

Można było zaobserwować dwie tendencje. Pierwsza traktowała judaizm jako odrębną religię, druga uznawała, że jest to zagrożenie dla chrześcijaństwa na równi z herezjami. Odbiór judaizmu jako zagrożenia wywodził się z kręgów kościelnych z początków średniowiecza: wówczas uznano, że judaizm to nie osobna religia, a odstępstwo od prawdziwej wiary chrześcijańskiej, która znana była Żydom bardzo dobrze (Trachtenberg 1997). Z czasem jednak Kościół dokonał oficjalnego rozróżnienia między innowiercami a heretykami, aby uniknąć dwuznaczności i niezrozumienia. Na mocy pism kościelnych tzw. niewierni, czyli Żydzi, muzułmanie i poganie byli wyłączeni spod działania inkwizycji, w przeciwieństwie do heretyków. Małżeństwa mieszane (żydowsko-chrześcijańskie) były jednak surowo zabronione pod groźbą potępienia, ekskomuniki, a nawet kary śmierci.

Kolejną powodem traktowania Żydów jako radykalnie „innych” było, poza religijnością, przekonanie o ich uzdolnieniach magicznych. Wiara $\mathrm{w}$ to, że Żydzi parają się czarami wywodziła się jeszcze ze starożytności i została przejęta przez średniowiecze. Powszechna opinia głosiła, że żydowskie uzdolnienia magiczne pochodzą od Mojżesza, uznanego za jednego z największych magików wszystkich czasów (por. ibid.). Język hebrajski, z powodu jego nieznajomości wśród nie-Żydów, uważano za skuteczny nośnik treści magicznych. Poza zdolnościami magicznymi, Żydzi zasłynęli jako wróżbici, podkreślano także ich zaawansowanie w alchemii (zaliczanej wręcz do żydowskiej specjalności, mimo stosunkowo małej liczby żydowskich alchemików). Duży wpływ na taki odbiór Żydów odegrała Kabała, choć znana jeszcze $w$ średniowieczu, to poznana przez chrześcijan ( $w$ ograniczonym zakresie) dopiero w wieku XVI.

Wraz z rosnącą nieufnością w stosunku do Żydów i innowierców zaczęto inaczej oceniać żydowskie społeczeństwo. Funkcjonująca w przesądach postać Żyda-czarownika_powoli stawała się synonimem sił diabelskich. Od XIII wieku coraz częściej pojawiały się poglądy, że do swych obrzędów magicznych Żydzi wykorzystują hostie oraz dokonują mordów rytualnych. Ten drugi zarzut był oskarżeniem wysuwanym najczęściej przeciw Żydom. Na nim opiera się większość działań antysemickich. Joshua Trachtenberg pisze:

Ze wszystkich dziwacznych oskarżeń przeciwko Żydom tym, które przetrwało najdłużej i zyskało największy rozgłos, a także spowodowało najbardziej ponure konsekwencje, jest tak zwane 
oskarżenie o mord rytualny. W wersji popularnej znaczy to, że rytuał żydowski na święto Pesach wymaga krwi chrześcijańskiej (ibid. 112).

Wprawdzie wyżsi rangą przedstawiciele Kościoła katolickiego starali się zahamować rozprzestrzenianie takich oskarżeń, jednak niższe duchowieństwo przedstawiało zbrodnie dokonywane rzekomo przez Żydów, by pogłębić przed nimi strach. Wystarczyła śmierć lub nawet tylko zniknięcie jakiegoś dziecka, by rzucić na społeczność żydowską oskarżenia o rytualną zbrodnię. Papieże czuli się zobowiązani do zapewnienia Żydom ochrony przed tego typu oskarżeniami, zdając sobie sprawę z daleko idących konsekwencji rozsiewania paniki i nienawiści wśród prostego ludu.

Paradoksalnie zarzuty o popełnienie rytualnych zbrodni pojawiły się jeszcze w starożytności i nie dotyczyły tylko Żydów.

Doskonale wiadomo, że w pierwszych wiekach chrześcijaństwa sami chrześcijanie często bywali oskarżani przez pogan o zabijanie i składanie w ofierze małych dzieci. ... Jeśli chodzi o Żydów, oskarżenie to nie pojawia się więcej aż do XII wieku, w którym przywrócono je nagle do życia (Trachtenberg 1997, 114).

Oskarżenia o mord rytualny podkreślały tradycyjną nienawiść Żydów do chrześcijan, łącząc się ze wspomnianym już przekonaniem o szatańskim pochodzeniu Żydów. W XIV wieku do oskarżeń o mordy rytualne wniknęły pseudo-wyjaśnienia dotyczące tego, w jakim celu Żydom potrzebna jest krew chrześcijan: do wyrobu macy bądź mieszania jej z winem na święto Pesach.

Nieświadomość wszystkiego, co wiąże się z religią żydowską, kazała ludziom nader pochopnie dopatrywać się diabolicznych intencji magicznych, zwróconych przeciwko chrześcijanom, w zgoła niewinnych czynnościach rytualnych, które skłaniały do podejrzliwości przez samą obcość (ibid. 84).

Aby uniknąć prześladowań, niektórzy rabini zalecali daleko idącą ostrożność w wypełnianiu pewnych judaistycznych rytuałów. Dla zwykłego człowieka, łatwo poddającego się manipulacji duchownych, to, co było niezrozumiałe, a wywodziło się z innej wiary, z miejsca stawało się co najmniej podejrzane - a często uznawane było za dowód na powiązania z diabłem bądź uprawianie czarnej magii.

Getto współcześnie rozumiane jest bardzo pejoratywnie, jako miejsce izolujące Żydów od reszty społeczeństwa, jako miejsce stygmatyzujące. Mieszkaniec getta traktowany jest jako ktoś gorszy, przed kim trzeba się chronić. W momencie tworzenia się getta, cel jego powstania oraz jego funkcje były zdecydowanie inne.

Pierwsze getto powstało w 1516 roku w Wenecji. Jego utworzenie było efektem długotrwałych działań Żydów weneckich, którzy pragnęli mieć oficjalnie potwierdzone prawo do zamieszkania w jednej z weneckich dzielnic. Tak oficjalnie wyznaczone miejsce uznane było za ważny przywilej. Jednak już 
w XVI wieku odrębna dzielnica żydowska zaczęła nabierać specyficznego charakteru. Getta zaczęto tworzyć w innych miastach, np. w Rzymie, w 1555 r., z polecenia papieża Pawła IV. Każde getto było zamykane na noc i pilnowane przez wyznaczoną straż, aby żaden jego mieszkaniec (za wyjątkiem lekarzy grupy wyjątkowo uprzywilejowanej) nie opuszczał jego terenu aż do rana. Początkowo słuszna idea zaczęła się wypaczać: getta (niekoniecznie zamierzenie) zaczęły izolować Żydów od pozostałych mieszkańców danej okolicy, szybko też—na skutek zbyt dużej liczby osób w stałej, ograniczonej przestrzeni-zaczęły zmieniać się w ubogie, zaniedbane dzielnice.

Czasami zezwalano na powiększenie terenu, ale $\mathrm{w}$ znakomitej większości przypadków pierwotne granice gett zostawały zachowane. Stąd też, nawet jeśli dzielnice, w których powstawały getta, nie były slumsami, szybko się nimi stawały (Abrahams 1996, $56)$.

Skupienie się Żydów w odrębnych częściach miasta nie stanowiło novum, ponieważ była to praktyka powszechnie stosowana. Niemal wszędzie Żydzi i chrześcijanie, żyjąc $\mathrm{w}$ jednej społeczności, izolowali się wzajemnie. ${ }^{1}$ Getto stanowiło pewnego rodzaju ochronę dla chrześcijan (duchowni starali się zapobiegać sytuacjom, gdy chrześcijanie będą chcieli przejść na judaizm). Getto jako ośrodek zamieszkania Żydów łączył osoby odmiennego pochodzenia, różniące się nierzadko językiem, pewnymi rytuałami religijnymi i doświadczeniem życiowym (Callimani 2002). Obecność barwnych osobowości sprawiała, że getta stawały się miejscem, skąd wywodzili się wybitni żydowscy intelektualiści.

Znaczna liczba Żydów studiowała: z całych Włoch studenci żydowscy pobierali nauki na uniwersytecie w Padwie, który cieszył się wielka sławą. Godne podkreślenia jest, iż studenci żydowscy nie byli segregowani i izolowani od reszty. Z getta wywodzili się znakomici lekarze, pisarze, artyści i intelektualiści żydowscy.

Przed odrodzeniem humanistycznym Żydzi byli zapewne najlepiej wykształconą grupą narodową wśród ludności Europy. Przeciętny Żyd zawsze umiał pisać i czytać (Abrahams 1996, 229).

Zmiana nastąpiła dopiero $\mathrm{w}$ renesansie. Wówczas doszło nie tylko do pogorszenia metod nauczania, lecz również ograniczenia bogactwa kultury żydowskiej. W średniowieczu wśród Żydów panowała rozpowszechniana przez rabinów zasada: nauka moralna musi być połączona z intelektualną. Mimo częstego przemieszczania się, Żydzi średniowieczni nie posługiwali się żargonami; zarówno w mowie, jak i piśmie używali języka danego kraju, posługując się nim płynnie i z precyzją. Byli dwujęzyczni, ponieważ ich „wewnętrznym” językiem pozostawał hebrajski. Niechęć Żydów do

${ }^{1}$ Idzie tu bardziej o izolację fizyczną, polegającą na zamieszkiwaniu w osobnych dzielnicach czy częściach miasta. Taka izolacja nie dotyczyła współpracy handlowej czy też intelektualnej. 
posługiwania się łaciną była dość prozaiczna: był to język kościelny (Abrahams 1996).

Średniowieczni żydowscy lekarze byli osobami powszechnie szanowanymi i cieszyli się opinią znakomitych fachowców; mogli z nimi konkurować jedynie Maurowie (dotyczy to zwłaszcza Żydów z Hiszpanii i Włoch) (ibid.). Jako jedyna grupa społeczna w getcie, zachowali ono prawo do opuszczania go nocą, by móc odwiedzać swoich pacjentów.

Nieustannie podejmowano wysiłki, by Żydów usunąć, ale ani królowie, ani nawet sami papieże nie byli w tym względzie posłuszni kanonom Kościoła. Gdy chrześcijańskie uniwersytety zaczęły uczyć medycyny w naukowy sposób, żydowska i arabska dominacja w tej dziedzinie zmarła śmiercią naturalną. Jednakże aż do tego czasu nie było chyba w Europie dworu ani biskupstwa, które nie korzystałyby z usług żydowskiego lekarza (ibid. 161-162).

W Wenecji Żydzi stworzyli ośrodek wydawniczy, który szybko zyskał międzynarodową sławę i był ceniony ze względu na swą wysoką jakość:

Przyciągnięci tym korzystnym klimatem, przybywali tu z całej Italii i z całej Europy żydowscy intelektualiści, którzy chcieli pracować w branży drukarskiej, a także uczeni, pragnący opublikować swoje książki. Debata kulturalna $\mathrm{w}$ getcie przyczyniła się do rozpowszechnienia książki żydowskiej we wszystkich krajach śródziemnomorskich i obficie zaowocowała dziełami z dziedziny filozofii, gramatyki i religii, co pozwoliło zawrzeć w książkach starannie drukowanych i bogato zdobionych najważniejsze kierunki myśli rabinicznej owego czasu i wieków poprzednich (Callimani 2002, 117-118).

Poza osiągnięciami w dziedzinie druku czy medycyny, Żydzi byli cenieni jako teologowie. Rabini nierzadko dyskutowali z teologami chrześcijańskimi. Środowisko getta, łącząc w sobie różne nacje, sprzyjało powstawaniu nowych idei intelektualnych.

Żydzi tłumaczyli z języka arabskiego na hebrajski i pomagali swym chrześcijańskim przyjaciołom $\mathrm{w}$ przekładach $\mathrm{z}$ hebrajskiego na łacinę. Żydzi włoscy nie wykazywali się oryginalnością, ale oddali ogromne usługi jako tłumacze literatury medycznej, naukowej, filozoficznej, a nawet folklorystycznej (Abrahams 1996, 277).

Jak można zauważyć, w oczach średniowiecznej społeczności wizerunek Żyda jest więc niejednolity, chwilami nawet jego charakterystyki są nie tylko ambiwalentne, lecz także wzajemnie sprzeczne. Żydowskość kojarzona jest z magiczną mocą, diabolicznością, postawą wrogości wobec chrześcijan-a jednocześnie z kupiecką zaradnością, talentami predysponującymi do parania się sztuką medyczną, ponadprzeciętnym intelektem i wykształceniem, a także temperamentem polemicznym pozwalającym Żydom wdawać się $\mathrm{w}$ debaty $\mathrm{z}$ uczonymi z kręgu chrześcijańskiego. Większość prześladowań rodziła się 
wówczas dzięki (mniej lub bardziej wyraźnym) antagonizmom w łonie Kościoła, co wedle Abrahamsa miało za cel nakłonienie Żydów do konwersji na wiarę chrześcijańską ${ }^{2}$. Warto jednak podkreślić, że mimo niepokojów, jakie czasowo wzbierały $\mathrm{w}$ relacjach między żydowską i nieżydowską częścią społeczności okresu Średniowiecza, wzajemne stosunki między nimi nadal można było określić jako pokojowe.

Fot. 1. Teren getta weneckiego współcześnie (fot. T. Jaroszewski, 2014)

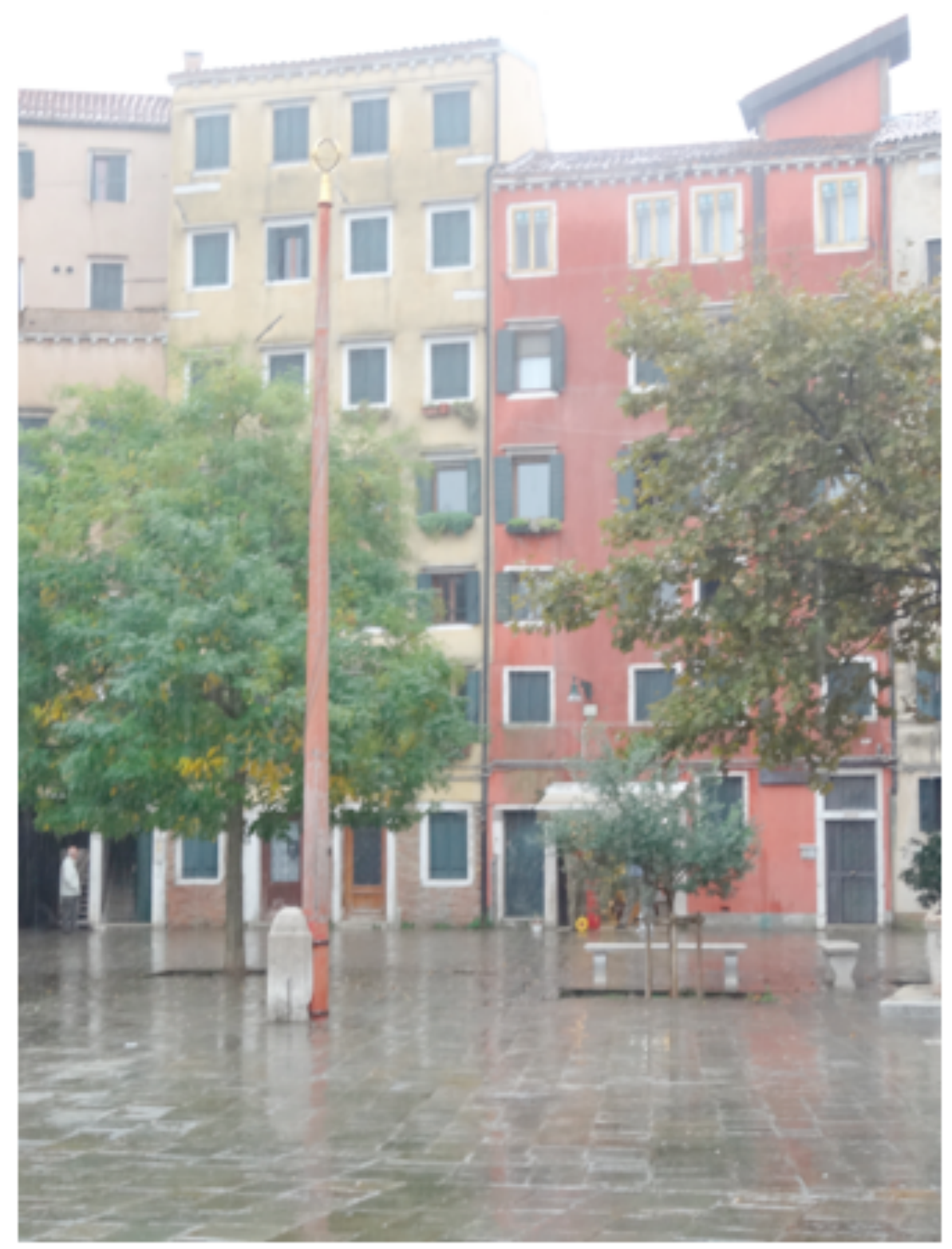

2. Fot. T. Jaroszewski (2014)

2 Sami Żydzi nie zabiegali o to, by kogokolwiek nawrócić na judaizm, wychodząc z założenia, iż nie-Żydzi również osiągnąć mogą zbawienie. 

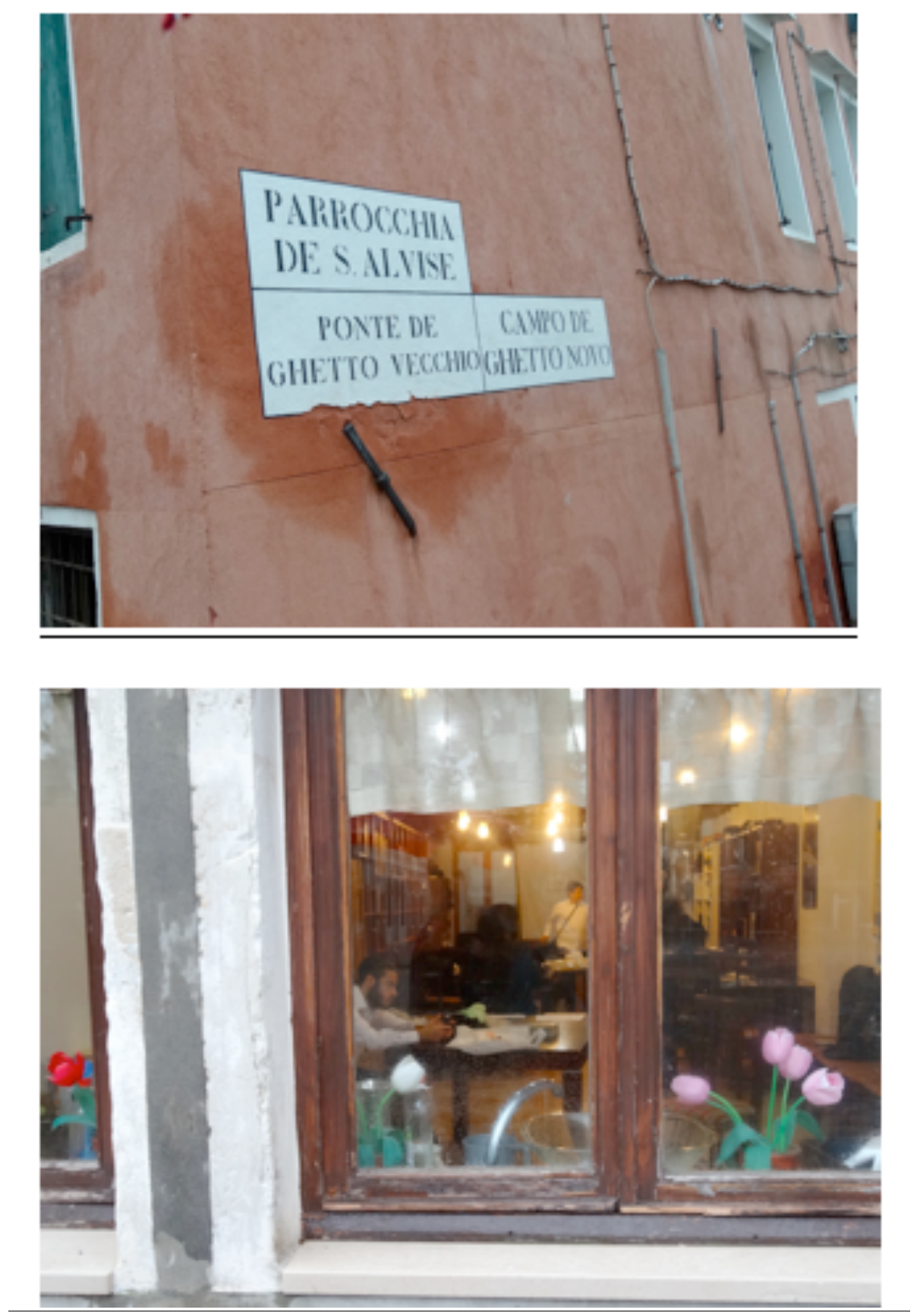

Fot. 3. W średniowiecznych budynkach funkcjonuje współczesna społeczność żydowska (fot. T. Jaroszewski) 


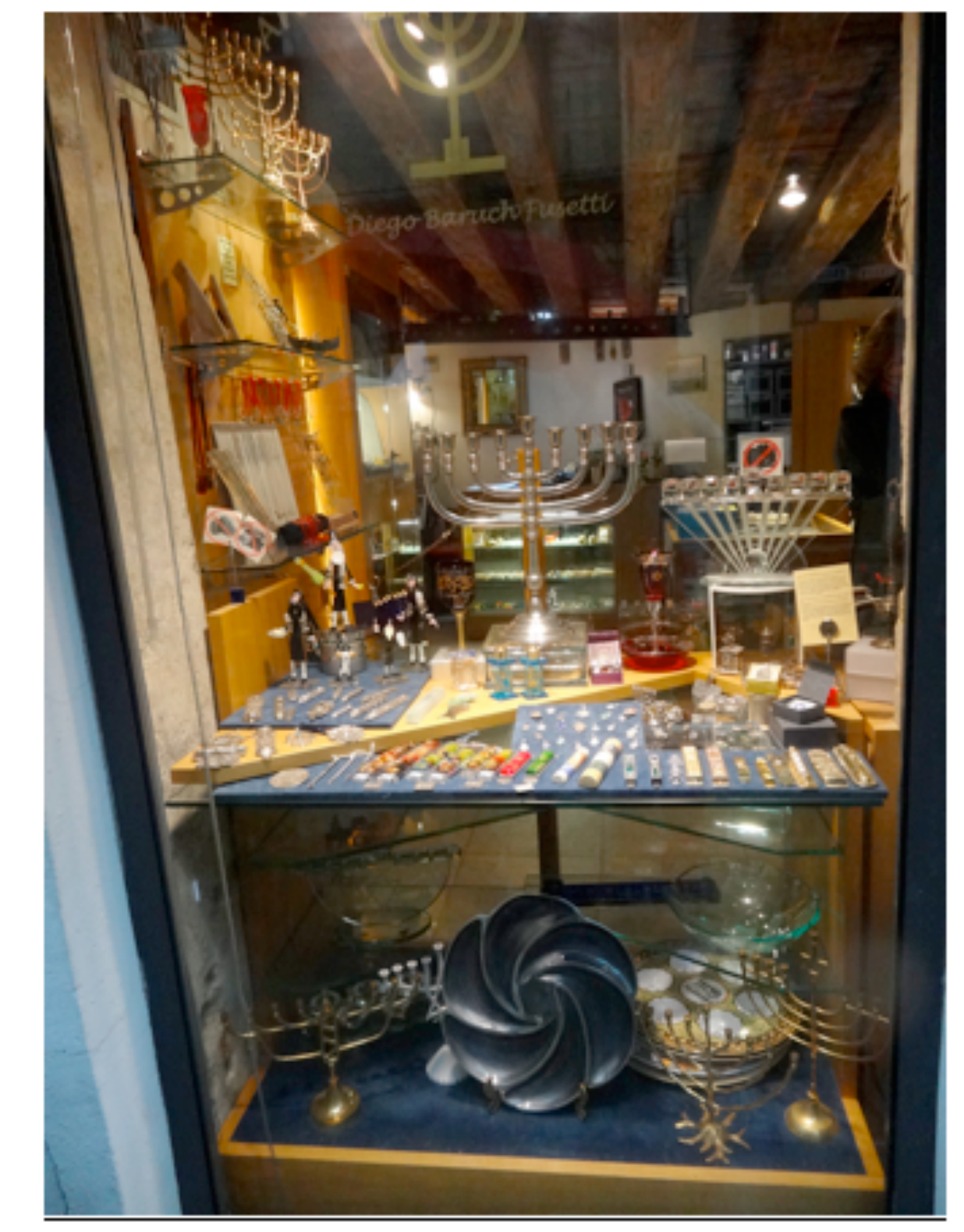

Fot. 4. Sklep z tradycyjnymi utensyliami w jednym z budynków dawnego getta weneckiego (fot. T. Jaroszewski)

\section{Literatura}

Abrahams, I. 1996. Życie codzienne Żydów w średniowieczu. Tłum. В. Gadomska. Warszawa: Cyklady.

Callimani, R. 2002. Historia getta weneckiego. Tłum. T. Jekielowa. Warszawa: Czytelnik.

Le Goff, J. 1970. Kultura średniowiecznej Europy. Tłum. H. SzumańskaGrossowa. Warszawa: Państwowe Wydawnictwo Naukowe. 
Trachtenberg, J. 1997. Diabeł i Żydzi. Średniowieczna koncepcja Żyda a współczesny antysemityzm. Tłum. R. Stiller. Gdynia: URAEUS.

\title{
Anna Jaroszewska (Poznań)
}

\section{Wizerunek średniowiecznego Żyda Drawing a Medieval Jew`s Picture}

\begin{abstract}
Medieval Jews were perceived by their neighbors in two ways. On the one hand, as an integral part of the community, living among Christians, leading business or cooperating intellectually with them. Jewish philosophers were known and respected by Christian thinkers, like the Jewish medics prized for centuries for their extensive knowledge and skills. On the other hand, the medieval Jew is a clever merchant, cunning moneylender that is gathering his fortune, follower a foreign religion - full of incomprehensible mysterious rituals. Although there was no shortage of sympathy, Jews were rather approached with distrust and distance. A perfect example of this is the ghetto, created in medieval times. Medieval Jew's pictures are multidimensional and very interesting. The article offers an attempt to present this diversity, discussing the Jew as a merchant, usurer, a resident of the ghetto, dissenter and a member of medieval society.
\end{abstract}

Keywords: Ghetto, usury, the Jews, Middle Ages

Doi:10.14746/eip.2014.2.18 